ROCZNIKI PEDAGOGICZNE

Tom 13(49), numer $2-2021$

DOI: https://doi.org/10.18290/rped21132.5

ALINA RYNIO

\title{
ODPOWIEDZIALNOŚĆ TRAJEKTORIĄ W ŚWIAT DOBRA
}

W niniejszej publikacji chciałabym skoncentrować uwagę zainteresowanych podjętą problematyką wokół próby odpowiedzi na trzy zasadnicze pytania:

1) Czym jest odpowiedzialność i kiedy staje się trajektorią - prowadzącą w ,świat dobra”?

2) Jakie warunki są niezbędne, aby taka odpowiedzialność zaistniała?

3) Jak jest rozumiane samo dobro i co kryje się w pojęciu szeroko rozumianego ,świata dobra”?

\section{ISTOTA, TREŚĆ I ZAKRES POJĘCIA „ODPOWIEDZIALNOŚĆ”"2}

Chcąc odpowiedzieć na pytanie pierwsze, należy zauważyć, iż w języku potocznym pojęciem odpowiedzialności posługujemy się bardzo często. Czynimy to w wielu sytuacjach i w różnych znaczeniach. Analiza pojęcia „odpowiedzialność" wymaga odpowiedzi na wiele pytań dotyczących jej sensu, kontekstu, granic i znaczenia ${ }^{3}$. Wnikliwa analiza semantyczna terminu „odpowiedzialność”

Dr hab. Alina RYNIO - Katedra Pedagogiki Chrześcijańskiej i Biografistyki Pedagogicznej, Instytut Pedagogiki, Wydział Nauk Społecznych, Katolicki Uniwersytet Lubelski Jana Pawła II; adres do korespondencji: Al. Racławickie 14, 20-950 Lublin; e-mail: alina.rynio@kul.pl; ORCID: https://orcid.org/0000-0003-4113-7620.

${ }^{2} \mathrm{~W}$ tej części artykułu odwołam się do wybranych argumentów zaprezentowanych w dwóch wcześniejszych publikacjach mojego autorstwa: $A B C$ wychowania do odpowiedzialności (2011) i Wychowanie do odpowiedzialności. Zarys teorii i praktyki pedagogiki integralnej (2019).

${ }^{3}$ Przykładem takiej analizy jest niezwykle bogata i inspirująca twórczość jednego z najwybitniejszych polskich fenomenologów, Romana Ingardena. Będąc przedstawicielem obiektywistycznej orientacji w szkole fenomenologicznej, swoje przemyślenia dotyczące odpowiedzialności zawarł w publikacji pt. Książeczka o człowieku (1972, 2017) (zbiór studiów antropologicznych). 
pozwala stwierdzić związek odpowiedzialności z odpowiedzią na to, co się człowiekowi wydarza i co go spotyka (Budajczak, 1995) ${ }^{4}$. Słowo „odpowiedzialność" ma różne znaczenia, a jego sens zmienia się w zależności od kontekstu - sytuacji czy intencji rozmówcy. Najczęściej bywa rozumiana jako postawa wynikająca ze świadomości i wolności, pozwalająca na podejmowanie decyzji i przyjmowanie ich konsekwencji. Dotyczy słów, myśli, czynów ludzkich i zaniedbań. Jeżeli więc człowiek podejmuje działanie, wiedząc, czego chce i dlaczego tego chce, oraz czyni to dobrowolnie, tj. bez żadnego przymusu zewnętrznego, wówczas musi też przyjąć odpowiedzialność zarówno za poziom wykonania, jak i za skutki podjętego działania. W tym miejscu trzeba też przywołać tezę, iż człowiek jako istota rozumna jest zdolny przyjąć taką odpowiedzialność, zaś nie wymuszony udział w realizacji działań zbiorowych nie może zwolnić go od odpowiedzialności przez fakt, że decyzję podejmowała większa liczba ludzi. Co więcej, im większy przymus w działaniach, tym mniejsze poczucie odpowiedzialności (Jagiełło, 1990, s. 151).

Analiza zjawiska odpowiedzialności, by była rzetelna, musi uwzględniać złożoność ludzkich działań i musi być wielokierunkowa. Pisze o tym Marek Rembierz, przywołując przekonywające świadectwo Danuty Gierulanki uczennicy Romana Ingardena, roztrząsającego podstawowe kwestie ontologiczne umożliwiające przypisanie człowiekowi jakiegoś zakresu i typu odpowiedzialności oraz wybór stanowiska w kontrowersjach dotyczących istnienia wartości zespolonych z potrzebą odpowiedzialności (Rembierz, 2008, s. 272). Cytuję:

\begin{abstract}
Jak zauważa - na kanwie rozprawy Romana Ingardena $O$ odpowiedzialności i jej podstawach ontycznych (pierwsze wydanie po niemiecku w Stuttgarcie w 1970 r.)

- Danuta Gierulanka, ,aby odpowiedzialnie mówić o odpowiedzialności i uznać jej obowiązywanie w życiu ludzkim, trzeba przyjąć pewne rozstrzygnięcia co do istnienia wartości, co do możliwości utrzymania się tożsamości osoby ludzkiej, co do istnienia przynajmniej pewnego zakresu jej wolności [...], a w końcu pewnej specjalnej struktury przyczynowości świata [...] [i] systemów względnie izolowanych od siebie. [...]. Analiza zjawiska odpowiedzialności - kontynuuje autor aby zasługiwała na miano „odpowiedzialnej”, musi uwzględniać złożoność sytuacji ludzkich działań i być wielokierunkowa (1972, s. 86).
\end{abstract}

Chcąc uniknąć niebezpieczeństwa bezrefleksyjnego posługiwania się „dobrze brzmiącym” pojęciem „odpowiedzialność”, warto zatrzymać się na próbie logicznej analizy jego struktury przeprowadzonej przez J. M. Bocheńskiego,

\footnotetext{
${ }^{4}$ Szczegółowy opis znaczenia słowa „odpowiedzialność” można znaleźć w artykule M. Budajczaka (1995, s. 51-57).
} 
zawartej w rozprawie $O$ kilku zagadnieniach dotyczacych logicznej struktury odpowiedzialności (Bocheński, 1995, s. 9-12; por. Wolsza, 2005, s. 183-205), czy analizach pojęć „powinność” i „odpowiedzialność” dokonanych za pomocą narzędzi semiotyki logicznej przez Leona Koja w książce Powinności w nauce (1998).

W Encyklopedii katolickiej możemy przeczytać, iż „odpowiedzialność jest czymś więcej niż tylko poczuciem obowiązku; wykracza poza wypełnienie określonych powinności i zadań; wyrażając się przez czyn, osoba musi zważać na zewnętrzny wymiar swojej aktywności, gdyż jej działania lub zaniechanie ich mają też wpływ na innych ludzi”" (Derdziuk, 2010, kol. 334-335).

W gazetach, publicystycznych audycjach telewizyjnych i radiowych słowo „odpowiedzialność” pojawia się często w różnych kontekstach i jest odmieniane przez wszystkie przypadki. Jednak po przeanalizowaniu jego potocznych definicji łatwo można dojść do wniosku, że odpowiedzialność bardzo często jest rozumiana jako ponoszenie konsekwencji za łamanie obowiązujących $\mathrm{w}$ społeczeństwie reguł i zasad. $\mathrm{W}$ powszechnym mniemaniu człowiek ponoszący odpowiedzialność to ktoś, kto został skazany prawomocnym wyrokiem sądu (jeśli złamał prawo), lub ktoś winny spowodowania negatywnych zjawisk, za co zostaje napiętnowany społecznie. W tym kontekście odpowiedzialność łączy się zazwyczaj z winą i karą. „Dlatego też odpowiedzialność dzieci i młodzieży - jak słusznie zauważa komentująca tę kwestię B. Krzywosz-Rynkiewicz - kojarzy się najczęściej z utrzymaniem porządku w klasie, dobrą dyscypliną i «byciem grzecznym». Nauczyciele i rodzice, mówiąc, że chcą mieć odpowiedzialne dzieci, mają zwykle na myśli dzieci wywiązujące się z obowiązków i respektujące zasady ustalone w domu i szkole” (2007, s. 9). O tym, że pod pojęciem „odpowiedzialność” kryją się inne, dużo głębsze znaczenia, trudno jest usłyszeć zarówno w dyskusjach prywatnych, jak i toczących się w mediach. A przecież odpowiedzialność to nie tylko postępowanie według ustanowionych w społeczeństwie norm i zasad. To również rozumienie reguł, akceptacja i traktowanie ich jako własnych. Odpowiedzialność ma w sobie element poczytalności, świadomej zgody i wolności wyboru, a akceptacja norm i reguł nie jest człowiekowi dana wraz z urodzeniem, ale rozwija się wraz z upływem czasu i zdobywanym doświadczeniem. Może też oznaczać cechę charakteru, właściwość osobowości. Jest ona konfrontowana z naszą wiedzą, doświadczeniem, z odmiennymi punktami widzenia ludzi, z którymi przebywamy stale lub spotykamy się sporadycznie. 
Odpowiedzialność jest terminem występującym w wielu dziedzinach życia społecznego, nie wyłączając filozofii (Schwartländer, 1995; Filek, 1995, 1998, 2004; Woleński, 1995; Jadacki, 2003; Ingarden, 1972; Plašienková, 1998), etyki (Filek, 1993; Ślipko, 1993), historii, prawa, edukacji czy wychowania (Górniewicz, 1994, 2001; Ingarden, 1994; Kościelska, 2007; Sośnicki, 1973; Kazubowska, 2010; Rapa, 2013). Najczęściej i najwięcej mówią o odpowiedzialności politycy, dziennikarze oraz ideolodzy życia społecznego. Na gruncie pedagogiki i wychowania również operuje się tym pojęciem w różnych kontekstach, w zależności od tego, kto się wypowiada. Inaczej czynią to politycy, inaczej osoby duchowne, a jeszcze inaczej profesjonalni wychowawcy czy rodzice, nie mówiąc o historykach, etykach, filozofach, prawnikach czy ekonomistach. W związku z tak różnorodnymi wypowiedziami można postawić tezę, że wśród kategorii pedagogicznych, odpowiedzialności przypada rola szczególna, a zawarta w niej problematyka obejmuje niezwykle ważny obszar zagadnień psychopedagogicznych. Odpowiedzialne funkcjonowanie człowieka jest bowiem jednym z wymiarów jego dojrzałości, a uczenie ludzi odpowiedzialności należy do podstawowych kategorii pedagogicznych. Dzieje się tak za sprawą tego, że odpowiedzialność jest podstawą samorealizacji człowieka, jego moralności i więzi społecznych. Istotą odpowiedzialności jest to, że człowiek sam przyczynia się do osiągania własnego dobra i dobra innych.

Odpowiedzialność oznacza też cechę moralnego postępowania osoby ludzkiej, która wypływa z jej dobrowolności. W sensie sprawstwa aksjologicznego odpowiedzialność oznacza stan rzeczy, w którym skutki działania (również poprzedzająca je intencja) są podstawą oceny człowieka, jako sprawcy tych skutków, $\mathrm{z}$ perspektywy określonego systemu reguł moralnych (Chłodna-Błach, 2016). Być odpowiedzialnym znaczy świadomie udzielić odpowiedzi na wyzwania, które przynosi rzeczywistość - zwłaszcza w tym jej wymiarze czy obszarze, który został człowiekowi powierzony (Bobiński, 2007). Człowiek odpowiedzialny troszczy się o to, co zostało mu powierzone przez Boga, o swoje powołanie. Kieruje się w działaniu normami moralnymi, wypełnia swoje zobowiązania wobec rodziny, narodu, ojczyzny i świata. Troszczy się o dobro swoje, a także innych osób. Dba o swoje otoczenie i jest gotów do ponoszenia konsekwencji pozytywnych lub negatywnych skutków własnych decyzji podejmowanych świadomie i dobrowolnie.

Najbardziej kompetentną instancją, przed którą zdaje sprawę ze swoich działań i weryfikuje swą ludzką i zawodową odpowiedzialność, jest on sam - jego sumienie. To właśnie ono - ostatecznie - rozstrzyga o moralnej ocenie 
działań, a tym samym o ich podejmowaniu bądź ich odrzucaniu. Jednak warunkiem rzetelnej oceny jest prawidłowo ukształtowane sumienie i niekłamanie samemu sobie. Można zatem powiedzieć, że odpowiedzialność jest nie tylko pożądaną cechą oznaczającą solidność, zdyscyplinowanie, słowność czy spolegliwość, lecz także postawą człowieka, która przejawia się zarówno $\mathrm{w}$ stosunku do samego siebie, jak i w relacji do innych oraz w stosunku do wykonywanych zadań. Dlatego też

\footnotetext{
Wychowanie do odpowiedzialności staje się tym bardziej potrzebne, im bardziej w świecie współczesnym zanika poczucie odpowiedzialności, a nawet pojawia się świadome jej odrzucenie. W kontekście współczesnego zagubienia i zafałszowania ludzkiej wolności być może najważniejszym aspektem wychowania jest wychowanie do odpowiedzialności, a więc do odpowiedzialnej wolności - do wolności w duchu miłości (Skreczko, 2018).
}

W historii ludzkości zdarzały się okresy, w których postawa odpowiedzialna za podejmowane przez jednostkę czyny była bardzo mocno doceniana. Można jednak wskazać wiele sytuacji i przypadków, w których poczucie odpowiedzialności u ludzi słabło i nie było podejmowane ani w życiu, ani w procesie wychowania. Wówczas szczególną rolę do spełnienia mieli i mają wielcy myśliciele, pedagodzy, filozofowie i teolodzy, których zadaniem było i jest dowartościowanie kategorii odpowiedzialności i wychowania w życiu społecznym.

Zdaniem Józefa Górniewicza - znanego teoretyka wychowania - odpowiedzialność za słowa i czyny powinna należeć do kanonu dobrego wychowania. Dziś, w dobie elektronicznej cywilizacji, odpowiedzialność urasta do kwestii zasadniczej (1997, s. 13-14). Cytowany autor zauważa też, i trudno nie przyznać mu racji, że „,w obecnych czasach ta kategoria moralna jest doceniana i pożądana przez myślicieli i wizjonerów przyszłości, natomiast jest zupełnie niedoceniana przez ludzi polityki i biznesu" (2001, s. 211-212). Świadczyć o tym może inżynieria społeczna stosowana przez niektórych polityków, którzy twierdzą, że tradycyjne rodziny nie są już potrzebne, i promują model, w którym rodzice samotnie wychowują dzieci. Jeśli do tego dołączymy liczbę rodzin mieszanych i innych zmian w strukturze rodziny, nieprzewidywalność niezwykle szybko zmieniającego się świata, w którym żyjemy, nie zawsze zbawienny wpływ internetu i cyberprzestrzeni, kłamstwa i nieuczciwości, które nas otaczają, brak należytego przygotowania rodziców do rodzicielstwa, a nadto brak szacunku dla prawdziwych autorytetów, brak dyscypliny i nadmierne pobłażanie, wypaczony etos społeczny, który wywyższa wolność osobistą, nadając jej charakter absolutny, i zaprzeczenie dyscypliny, tzw. 
twardej miłości, i logiki oraz niejednokrotnie „groteskowy” system szkolnictwa, w którym nauczyciele boją się zwrócić uwagę wychowankowi na niewłaściwe zachowania i unikają oceniania, promując wśród uczniów poczucie samozadowolenia, to będziemy bliżej realnego świata, w którym żyjemy.

Analiza pojęcia „odpowiedzialność”, o której w Polsce zaczęto mówić głośno zwłaszcza po II wojnie światowej, w odpowiedzi na szereg pytań dotyczących jej sensu, kontekstu, granic i znaczenia, jest ważna szczególnie dziś, gdy lawinowo wzrasta liczba osób „uprzywilejowanych”, których przekonania destruktywnie wpływają na ich osobowość, a równocześnie preferowane są wybory, które wyboru nie dają, zaś zaangażowanie we własne sprawy jest traktowane jako wymówka dla własnej bezmyślności, egoizmu i wygody. „Uprzywilejowane osoby” żywią dwa rodzaje przekonań, które można określić jako „wysokie” i „niskie”. F. W. Cline i J. Fay, autorzy przewodnika dla rodziców, po stronie ,wysokich” destruktywnych przekonań „osób uprzywilejowanych" zamieścili: duże potrzeby w zakresie produktów i usług; dużo czasu na imprezowanie; wysokie wymagania w stosunku do innych; silny uraz wobec ludzi, którzy wymagają od nich osiągnięć poprzez ciężką pracę i podejmowanie wysiłków; duże zapotrzebowanie na rozrywki i nowe doświadczenia; wyraźne skłonności do sprzeciwiania się tradycyjnym zasadom i wartościom wyznawanym przez społeczeństwo; duże skłonności do nadużywania alkoholu i narkotyków. Po stronie zaś „niskich” przekonań, relatywnie do wyżej wymienionych, zamieścili: niską motywację do osiągnięcia sukcesu i pracy na własny rachunek; mało czasu na zdobywanie własnych osiągnięć; niskie ambicje; niedocenianie możliwości edukacyjnych; ograniczoną świadomość poświęceń ze strony rodziców; niewielki szacunek dla dorosłych i autorytetów; niski szacunek dla tradycyjnych wartości uznawanych przez społeczeństwo. Za takie przekonania u dzieci, które nie pojawiają się z dnia na dzień, ale ich podłoże tkwi w dzieciństwie, autorzy obarczyli winą rodziców, którzy nie potrafili wyznaczyć rozsądnych granic już na początku procesu wychowawczego (Cline, Fay, 2011, s. 211-212).

Warto zauważyć, iż z perspektywy analizy fenomenologicznej odpowiedzialność - zgodnie z sugestią R. Ingardena - może występować w czterech przypadkach:

1) ktoś ponosi odpowiedzialność za coś, czyli jest za coś odpowiedzialny;

2) ktoś podejmuje odpowiedzialność za coś;

3) ktoś jest za coś pociągany do odpowiedzialności;

4) ktoś działa odpowiedzialnie (Ingarden, 1972, s. 71-169). 
Wspomniana analiza semantyczna terminu „odpowiedzialność” pozwala stwierdzić jej związek z odpowiedzią na to, co się człowiekowi wydarza i co go spotyka (Budajczak, 1995, s. 51-57). Jak to można było zauważyć na podstawie powyższych analiz, słowo „odpowiedzialność” - podobnie jak słowo „wychowanie” - ma różne znaczenia i wymiary. Jego korzenie wywodzą się z łacińskiego czasownika respondeo, który pochodzi od słowa spondeo, i wydaje się mieć decydujące znaczenie dla idei odpowiedzialności. Być odpowiedzialnym oznacza też odpowiadać na apel, który niesie sytuacja, czas, w którym się żyje, historia, którą się tworzy, odpowiedzialność za porządek, ale przede wszystkim jest to odpowiadanie komukolwiek za jakość relacji, co w czasach, w których żyjemy, nabiera szczególnego znaczenia.

Znana polska socjolog M. Ossowska łączy odpowiedzialność z regułami życia zbiorowego. Pisze, że ze względu na pewne reguły ujęte w danej zbiorowości jest ona uprawniona do ukarania, postępowania lub pociągnięcia kogoś do pewnych świadczeń restrykcyjnych: „Wspólnie charakteryzuje te wypadki, potencjalne podleganie czyjemuś osądowi usprawiedliwionemu przez wspomniane reguły. Mówi się, że ktoś ma poczucie odpowiedzialności za swój czyn, gdy gotów jest poddać się zań tego rodzaju osądowi, przy czym w pewnych wypadkach bywa sam sobie sędzią" (1957, s. 33).

Na zakończenie tej części analiz jeszcze jedno spostrzeżenie: z etymologicznego słownika języka polskiego A. Bańkowskiego wynika, że „odpowiedzialność jest najmętniejszym z nowożytnych pojęć moralno-prawnych, dotąd ściśle nie zdefiniowanych, a oznacza ono, że człowiek odpowiedzialny to zdolny do sensownego odpowiadania, poczytalny, rozumny" (2000, s. 383). W nauce i sztuce, za sprawą powszechnie panującego relatywizmu, który nie ominął także tego pojęcia, mówiąc językiem J. P. Sartre’a - „stanęliśmy obecnie na skrzyżowaniu nieskończenie wielu dróg przed drogowskazem obracającym się chaotycznie i nieprzewidywalnie" (Jeliński, 2009, s. 83). Ten chaos i nieprzewidywalność są konsekwencją braku solidnej edukacji, która pozwoliłaby należycie zdiagnozować, nazwać, pokazać ideowe źródła i konsekwencje wszelkich zgubnych ideologii, które wnoszą totalny nieład moralny w życiu indywidualnym i wspólnotowym, połączony z zatraceniem, a nawet zbydlęceniem człowieka.

\section{ZDOLNOŚĆ ODPOWIADANIA CZŁOWIEKA ZA SIEBIE}

Potrzeba, możliwość i zdolność odpowiadania człowieka za siebie, za swoje uczucia, działania, integralny rozwój i myśli mogą być interpretowane 
jako szczególne cechy i wartości procesu dojrzewania do samodzielności, zdobywania autonomii osobowej, tworzenia się tożsamości i podmiotowości „dobrze wychowanego człowieka”, jego dorosłości jako integralnych składników oraz rezultatów procesu uspołecznienia w międzyludzkiej moralnej samoregulacji i edukacji.

Na przełomie lat 80. i 90. XX wieku, jak i w pierwszej dekadzie XXI wieku zostało wydanych kilka kluczowych pozycji, które stanowią fundament dla rozumienia treści pojęcia „odpowiedzialność” (Picht, 1981; Ingarden, 1972; Suchodolski, 1983; Wojtyła, 1960; Nowicka-Kozioł, 1993; Olbrycht, 1995; Jonas, 1993; Chudy, 2007; de Tchorzewski, 1998; Branden, 1999; Rutkowiak, 1990; Romanowska-Łakomy, 2001; Górniewicz, Michalak, 1998; Brezinka, 2005; Jeliński, 2009; Gałkowski, 2003; Czerepaniak-Walczak, 2007; Mari, 1999; Ablewicz, 2004; Kandia-Bednarz, 2007; Dykcik, 2010; Brodacka-Adamowicz, 1994; Chiona, 2001; Orsi, 2002; D'Arienzo, 2012; Miano, 2009; de Leo, 1996; Zavalloni, 1986; Caffarra, dal Covolo, 2012).

Do podjęcia problematyki wychowania do odpowiedzialności skłania m.in. propagowanie obecnie, bardziej niż kiedykolwiek, ideału człowieka odpowiedzialnego, przy równoczesnym braku realnej odpowiedzialności konkretnych osób i coraz gorszej kondycji globalnego społeczeństwa, szkoły, rodziny czy państwa. Dzieje się tak za sprawą trwającej wojny ideologicznej o serce i sumienie człowieka, o jego tożsamość i świadomość celu ludzkiego życia.

O tym, że pod pojęciem odpowiedzialności kryją się inne, dużo głębsze znaczenia, trudno jest usłyszeć zarówno w dyskusjach prywatnych, jak i toczących się w mediach, a przecież odpowiedzialność to nie tylko postępowanie według ustanowionych $\mathrm{w}$ społeczeństwie norm i zasad. To również rozumienie reguł, akceptacja i traktowanie ich jako własnych. Wszak odpowiedzialność ma w sobie element świadomej zgody i wolności wyboru, a akceptacja norm i reguł - jak to już zostało podkreślone - nie jest człowiekowi dana wraz z urodzeniem, ale rozwija się wraz z upływem czasu i zdobywanym doświadczeniem. Jest konfrontowana $z$ wiedzą, doświadczeniem, z odmiennymi punktami widzenia ludzi, z którymi przebywamy stale lub spotykamy się sporadycznie.

Dla współczesnego człowieka dysponującego coraz większymi możliwościami technologicznymi w dobie globalizacji, rozwoju społeczeństwa obywatelskiego i trwającej pandemii COVID-19 odpowiedzialność ma dodatkowe znaczenie. Jest to odpowiedzialność osobista za własne życie i życie najbliższych, umiejętność pełnego wykorzystania wszelkich możliwości w celu rea- 
lizacji swoich planów i pragnień w zgodzie z własnymi przekonaniami i przy respektowaniu obowiązującego prawa. Należy jednak pamiętać, że odpowiedzialność - poza kontekstem indywidualnym - ma też wymiar społeczny i obejmuje odpowiedzialność za dobro wspólne, którego istotną częścią jest drugi człowiek, rodzina, szkoła, społeczeństwo. W tym kontekście może zastanawiać, komu w świecie zależy na tym, aby Polacy zatracili swoją narodową tożsamość, wyrzekli się swej kultury narodowej i tego wszystkiego, co w niej najważniejsze, najwznioślejsze i najpiękniejsze, na masową skalę sami odchodzili od Kościoła i od wiary i stawali poza obiektywną prawdą, wolnością i dobrem?

\section{ZWIĄZEK ODPOWIEDZIALNOŚCI \\ Z WYCHOWANIEM INTEGRALNYM}

Niewątpliwie interesujące $\mathrm{z}$ naukowego punktu widzenia jest pytanie o związek odpowiedzialności z wolnością i wielorako definiowanym wychowaniem integralnym i skoncentrowaną na osobie pedagogiką integralną, z polem odpowiedzialności dziecka i dorosłego, z mentalnością świata, który coraz bardziej stawia na życie chwilą, natychmiastowe zaspokojenie każdej potrzeby, poprawność polityczną i „transakcyjność relacji”, jak również to, czy dzieci zaczynające uczestniczyć w życiu społecznym są gotowe do przejawiania zachowań odpowiedzialnych i - co może ważniejsze - jak inspirować ich rozwój w wymiarze odpowiedzialności podmiotowej?

Problem natury, genezy, sposobu funkcjonowania i wychowania do odpowiedzialności budził i budzi zainteresowanie wielu. Tym, co interesowało większość, był i jest problem oceny moralnej ludzkiej działalności i kształtowanie odpowiedzialności podmiotowej. Najczęściej jest ona rozpatrywana jako odpowiedzialność subiektywna (poczucie odpowiedzialności), rozumiana jako złożony konstrukt psychiczny, pełniący funkcję mechanizmu regulacji zachowania (Kościelska, 2007, s. 43; 2011). W edukacji humanistycznej jest ona traktowana jako postawa oraz postulat twórczego i elastycznego łączenia konieczności, powinności i potrzeby podejmowania sensownych działań podmiotowo-przedmiotowych, krystalizujących cechy jego osobowości według najbardziej uniwersalnych wartości ogólnoludzkich (Dykcik, 2010, s. 11).

W tym też kontekście wyjaśnienia domaga się związek wychowania do odpowiedzialności z teorią integralnego wychowania i praktyką edukacyjną, która otwiera człowieka na rzeczywistość, a nie na fikcje, mity, utopie i ideo- 
logie. Otóż teoria wychowania - jak stwierdza M. Nowak - zajmuje się analizą struktury procesu wychowawczego rozumianego integralnie, jako pewien byt jednolity, którego nie da się sprowadzić do funkcjonowania jedynie poszczególnych elementów. Wychowanie powinno zatem obejmować całego człowieka, jego życie fizyczne, zdolności spostrzegania i kojarzenia, aktywność intelektualną, życie uczuciowo-emocjonalne, wreszcie zdolności wyboru dobra i realizacji zamierzonych celów. Powinno zmierzać do tego, by wychowywany był zdolny do pełnej spójni myśli, słowa i czynu. Postulat harmonijnego wychowania powinien obejmować także całkowitą integralność treści, które są przekazywane w procesie wychowania (Nowak, 2008, s. 131132). Fundamentem tak rozumianego wychowania jest integralny rozwój, definiowany jako „całościowy zewnętrzny i wewnętrzny rozwój człowieka i przystosowanie do życia według przyjętego wzoru" (Rynio, 2004, s. 13), którym jest pełnia człowieczeństwa - w chrześcijańskiej koncepcji osiągana ostatecznie w Jezusie Chrystusie i przez Jezusa Chrystusa. Integralny rozwój sprowadza się do koordynacji i harmonii sfery fizycznej, psychicznej, społecznej, kulturowej, światopoglądowej w projekcie życia zdążającym do pełnego rozwoju osobowego. $Z$ kolei warunkiem tak rozumianego rozwoju jest integralne wychowanie, określane jako wspomaganie osoby wychowanka w drodze do osiągania pełni człowieczeństwa - w harmonijnym rozwoju potencjalności tkwiących w jego warstwie fizycznej, psychicznej, społecznej, kulturowej i światopoglądowej oraz ich integrowaniu ze sobą (Chałas, 2007). Wskaźnikiem tak rozumianego wychowania jest spójność myśli, słowa i czy$\mathrm{nu}$, zakorzeniona $\mathrm{w}$ dobru osobistym, integralnie związanym $\mathrm{z}$ tym, że edukacja powinna być harmonijna, co oznacza, iż: nie powinno jej brakować niczego istotnego, ważnego i wartościowego, a jej elementy winny tak do siebie pasować, by tworzyły uporządkowaną całość. W ten sposób rozumiano to już w czasach antycznych. Harmonia, do której dążono, była czymś więcej niż tylko czystą formalną harmonią sił duchowych. Nie chodziło o zdolność myślenia samą w sobie, ale o myślenie prawdziwe; nie o zdolność chcenia jako takiego, ale o chcenie dobra; nie o samą w sobie zdolność odczuwania, lecz o odczuwanie wartościowego. Edukacja harmonijna podmiotu nie byłaby do pomyślenia, podobnie jak nie do pomyślenia jest odpowiedzialność bez związania jej z dobrem obiektywnym i bez uwewnętrznienia kultury normatywnej własnego otoczenia. Za harmonijnie ukształtowanego uważano człowieka wtedy, gdy jego ład wewnętrzny odpowiadał ładowi zewnętrznemu natury i kultury. W skład tego wchodziło też zrozumienie dla porządku dóbr oraz trwała miłość prawdy, dobra i piękna (Brezinka, 2007, s. 144-151). 
Zanim odniosę się do dobra, chcę jedynie nadmienić, że szczegółowej analizie wychowania do odpowiedzialności poświęciłam liczącą 562 strony monografię tematyczną zatytułowaną Wychowanie do odpowiedzialności. Studium teorii i praktyki pedagogiki integralnej (2019). Ukazanie się publikacji, wydanej staraniem Wydawnictwa KUL w roku 2019, zostało zauważone nie tylko przez uczonych i znawców problematyki, ale przede wszystkim przez nauczycieli-praktyków (Rynio, 2019). W tej publikacji, w części I, ukazuję odpowiedzialność jako wartość zagrożoną, a zarazem problem edukacyjny. Wskazując na rozumienie istoty, zakresu i granic odpowiedzialności, piszę o niej jako o „wartości egzystencjalnie znaczącej i podstawie integralnego wychowania". Opisując różne aspekty i wymiary odpowiedzialności, podkreślam ,wybrane konteksty braku troski o wychowanie do odpowiedzialności”. Ów brak troski dostrzegam „w przemianach kulturowych i cywilizacyjnych o wymiarze globalnym, postmodernistycznej etyce globalnej, kryzysie wychowania i ucieczce od wartości, braku szacunku dla godności osoby, wartości życia ludzkiego i środowiska, jak również w deprecjonowaniu tradycji wychowawczej, rodziny, rodzimej kultury i religii. Wskazując na potrzebę i możliwości integralnego rozwoju i wychowania, dowartościowuję „ujęcie psychopedagogiczne” odpowiedzialności, zaś odnosząc się do podstaw wychowania do odpowiedzialności, zwracam uwagę na „wychowalność człowieka i przyczyny podejmowania działalności wychowawczej, a więc na godność, wolność i powinność moralną, na związek odpowiedzialności z wychowaniem moralnym i samowychowaniem". W części II omawiam „formowanie się koncepcji wychowania do odpowiedzialności w wybranych kontekstach refleksji nad człowiekiem". Trzecią część publikacji poświęcam „podmiotom i środowiskom wychowującym do odpowiedzialności”.

Pozwoliłam sobie szczegółowo przywołać treść tej publikacji z tego względu, że można w niej znaleźć odpowiedź na pytanie o to, jak realizować wychowanie do odpowiedzialności, aby było ono trajektorią ku dobru. W publikacji ukazałam także konkretne przykłady owej realizacji wychowania, respektujące odpowiedzialność jako egzystencjalną kategorię ludzkiego życia domagającą się permanentnej formacji i współpracy wszystkich wychowujących.

\section{DOBRO W SENSIE OGÓLNYM I SZCZEGÓŁOWYM}

Chcąc choćby tylko ogólnie przywołać specyfikę świata dobra, należy rozpocząć od uświadomienia sobie, co ją stanowi i co oznacza samo pojęcie 
„dobro”. Według P. Skrzydlewskiego „Dobro (gr. agathón, łac. bonum) to określona własność rzeczy lub działania moralnego człowieka; przedmiot właściwy woli; na gruncie poznania metafizycznego transcendentalna właściwość rzeczy wskazująca na pochodność (konieczny związek) bytu z wolą Boga lub też człowieka - twórcy" (2016, s. 256). Dla cytowanego autora pojęcie to oznacza też „cel i motyw, racja miłości, działania; ma znaczenie fundamentalne dla całej ludzkiej kultury, a w sposób szczególny dla samego wychowania człowieka" (tamże). W przywoływanym ujęciu kategoria dobra „jest kategorią analogiczną (ani jednoznaczną, ani wieloznaczną) związaną z różnymi dziedzinami bytu i świata ludzkiego; z tej racji wyróżnia się rozumienie dobra: w metafizyce jako sposobu bytowania rzeczy (wszystko, co istnieje, jest dobrem); w sensie ekonomicznym jako dziedzinę środków użytecznych do życia; w dziedzinie moralnej jako pewnej doskonałości uczynku człowieka i samego człowieka; w dziedzinie wytwórczej jako tego, co powstaje w wyniku tworzenia" (tamże).

Z kolei według S. Kowalczyka „Dobro, w sensie ogólnym oznacza wszystko to, co uważa się za wartościowe, pomyślne, pożyteczne oraz użyteczne dla osiągnięcia wyznaczonego celu” (1985, kol. 1373). Jak zauważa, „[...] w aspekcie bytowym dobro oznacza wartość, doskonałość bytu, jest przyporządkowane woli, jest czymś ku czemu wola zmierza, do czego dąży, ku czemu podąża. Dobro stanowi transcendentalną właściwość bytu i ma związek z bytem absolutnym" (tamże). Z kolei w aspekcie moralnym znaczy tyle, co świadome i wolne działania człowieka, zgodne z obiektywną normą moralności.

W sensie gospodarczym oznacza podstawę bytową, zaspokajającą materialne potrzeby człowieka stanowiące przedmiot gospodarowania. Dobro to obejmuje dobra fizyczne pochodzące z pracy (np. mieszkanie) lub z natury (np. ziemia, paliwa, surowce, drogie kamienie, szlachetne metale) i usługi, a także niektóre wartości i cechy osobiste człowieka, prawa, wartości kulturowe, jak i cechy przyrody.

W aspekcie społecznym dobro oznacza wartości służące jednostce oraz społeczeństwu, dlatego też możemy tu mówić o dobru publicznym i prywatnym mającym związek $z$ dobrem wspólnym (np. dobro rodziny, publiczne dobro Kościoła i państwa czy dobra prywatne osób fizycznych i prawnych, takie jak zdrowie, praca, sprawiedliwe za nią wynagrodzenie, ochrona prawna, własność prywatna, wolność religijna, prawo kształcenia się i wychowania, tworzenia i korzystania z dóbr kultury, udział w życiu publicznym, prawo do stowarzyszania się, do wyboru stanu i zawodu, do emigracji, a także 
prawo do swobodnego realizowania celów osobistych i społecznych, przysługujące z natury osobom zarówno fizycznym, jak i prawnym) (tamże, kol. 1374).

Przywołany autor zauważa, iż „Problematyka dobra interesowała już myślicieli starożytnej Grecji. Sokrates opowiadał się za Absolutnym charakterem dobra, upatrując najwyższą jego formę w cnocie. Platon rozumiał dobro jako bezbrakową doskonałość stanowiącą przedmiot ludzkich pragnień i dającą człowiekowi szczęście" (tamże). Dobro nie jest wyznaczone subiektywnymi przeżyciami człowieka (emocjonalnymi czy poznawczymi), lecz stanowi rzeczywistość obiektywną. Dobro rzeczy widzialnych wynika z partycypacji w świecie idei dobra będącej dobrem absolutnym. „Według Arystotelesa dobro jako cel wszelkiego dążenia, podobnie jak byt, ma zakres najogólniejszy" (tamże). Według Stagiryty istnieją dobra różnorodne - absolutne i relatywne, cielesne i duchowe, substancjalne i akcydentalne. Źródłem dobra bytowego jest głównie forma. U człowieka jest nią dusza ludzka i jej zmysłowe władze, czyli umysł i wola. Najważniejszym zaś dobrem jest Bóg - jako myśl samomyśląca. Z kolei Plotyn identyfikował dobro z Jednią i uważał je za źródło wszelkiego bytu (tamże).

Dobro stało w centrum uwagi myślicieli wczesnego średniowiecza. „Augustyn uznał je za fenomen pozytywny i uniwersalny. Rozróżnił dobro bytowe (powszechne) i moralne (pojawiające się w kręgu świata ludzkiego), dzięki czemu odciął się od naiwnego optymizmu aksjologicznego, wyróżniwszy dobra materialne, cielesno-zmysłowe i umysłowe (poznawcze, moralne i estetyczne), postulował harmonijny rozwój osobowości człowieka poprzez realizację wszystkich wartości oraz respektowanie ich naturalnej hierarchii; integralny element hierarchii upatrywał w istnieniu, które jest podstawą wszelkich wartości, a jego trwałość decyduje o randze dobra, dlatego niezmienny i zawsze istniejący Bóg jest summum bonum" (tamże).

Jednak teorię dobra najpełniej usystematyzował Tomasz z Akwinu, który rozgraniczył dobra bytowe, etyczne i pożądania, dobro godziwe, użyteczne i przyjemne, dobro uniwersalne i partykularne oraz absolutne i relatywne.

W filozofii nowożytnej współistniały różne interpretacje dobra, lecz przeważała tendencja relatywno-subiektywna. Na przykład T. Hobbes relatywizował dobro, uważając je za fenomen pochodny człowieka i identyfikując je głównie z przyjemnością. Z kolei G. W. Leibniz, przyjmując istniejący świat za najlepszy z możliwych, uznał uniwersalność różnorodnych form dobra. Subiektywistycznie zinterpretował ideę dobra F. Nietzsche. Pragmatyści głosili, że dobro posiada sens jedynie w odniesieniu do konkretnych jednostek czy grup pozostających w określonych sytuacjach działania (tamże, kol. 1375). 


\section{KONKLUZJA}

Chcąc zrozumieć dogłębnie świat dobra, z jego konotacjami, kategoriami i współczesnymi kwestiami w relacji do odpowiedzialności i wychowania, warto jeszcze sięgnąć po jakże bogate w tym względzie nauczanie Kościoła powszechnego, zwłaszcza zaś dokumenty Soboru Watykańskiego, zawarte w encyklikach nauczanie papieży (mam tu na względzie zarówno Jana XXII, Pawła VI, Jana Pawła II, Benedykta XVI, jak i papieża Franciszka), a także opracowane przez Papieską Radę Justitia et Pax Kompendium nauki społecznej Kościoła czy Katechizm Kościoła Katolickiego. Mając na uwadze odpowiedzialne wychowanie dokonujące się w kontekście uwarunkowań ponowoczesności, w jakiej przyszło nam żyć, warto pamiętać, że stawia ono wymóg realizmu wychowawczego pozwalającego na rozpoznanie zagrożeń i odważne podejmowanie prawidłowych decyzji wychowawczych, jak również konieczność wychowania integralnego, obejmującego sferę fizyczną, psychiczną, społeczną, moralną, kulturową i religijną. Pozwoli to nie tylko nie zagubić żadnego wymiaru życia, rozwoju i wychowania osoby, ale też ocalić całą prawdę o człowieku, jego naturze, powołaniu, godności i odpowiedzialności jako trajektorii wprowadzającej w świat dobra, prawdy, wolności, miłości i piękna. Aby to mogło mieć miejsce, niezbędne jest poznanie związku odpowiedzialności z poznaniem prawdy o sobie i o świecie, zdemaskowanie tego, co nie jest odpowiedzialnością, co nie jest prawdziwym dobrem, wolnością, prawdą, miłością, pięknem i wychowaniem. Jednak samo poznanie to dopiero początek, preludium do niezbędnego działania o charakterze pedagogicznym. Ucząc odpowiadania na to, „co w danym momencie wzywa”, wychowując do odpowiedzialności, trzeba wychowywać do uwagi, odważnej akceptacji prawdy, pozytywnego odniesienia do rzeczywistości i pamięci. Tymi, na których ciąży to zadanie, są rodzice, nauczyciele, wychowawcy, publicyści, szeroko rozumiane mass media, rodziny, narody, szkoły i środowiska pozaszkolne, uniwersytety, Kościoły, rządy państw, ruchy kościelne i formacyjne, grupy rówieśnicze i sami wychowywani. Respektując odpowiedzialność jako egzystencjalną kategorię ludzkiego życia i traktując wychowanie do odpowiedzialności jako pilną potrzebę i wyzwanie ciążące na wychowujących i wychowywanych, niezbędna jest zarówno znajomość czynników warunkujących występowanie i rozwój poczucia odpowiedzialności, jak również nieustanna formacja i współpraca wszystkich wychowujących. 


\section{BIBLIOGRAFIA}

ABLEwicz, K. (2004). Wychowanie do odpowiedzialności społecznej. Kraków: WAM.

AlbiŃsKa, E. (2004). Odpowiedzialność. W: T. PILCH (red.), Encyklopedia pedagogiczna XXI wieku (t. 3, s. 773-780). Warszawa: Wydawnictwo Akademickie „Żak”.

BAŃKOWski, A. (2000). Odpowiedzialność. W: A. MrozowsKA (red.), Etymologiczny słownik języka polskiego (t. 2, s. 383). Warszawa: Wydawnictwo Naukowe PWN.

BoBIŃski, W. (2007). Domena sumienia, czyli o odpowiedzialności. Znak, 6(625), 10-13.

BocheŃski, J. M. (1995). O kilku zagadnieniach dotyczących logicznej struktury odpowiedzialności. Tłum. K. Policki. Prakseologia, 1-2, 9-12.

Branden, N. (1999). Odpowiedzialność. Jak polegać na sobie i znaleźć sens życia. Tłum. E. Różalska, Łódź: Ravi, TeTa Publishing.

BrezINKA, W. (2005). Wychowanie i pedagogika w dobie przemian kulturowych. Tłum. J. Kochanowicz. Kraków: Wydawnictwo WAM.

BrezinKA, B. (2007). Wychowywać dzisiaj. Zarys problematyki. Tłum. H. Machoń. Kraków: Wydawnictwo WAM.

Brodacka-Adamowicz, E. (1994). Ideał wychowania w demokracji. Edukacja i Dialog, 5, 11-15.

BudAJCZAK, M. (1995). O pojęciu „odpowiedzialność” i jego okolicach. W: K. OlBRYCHT (red.), Edukacja aksjologiczna. T. 2: Odpowiedzialność pedagoga (s. 51-57). Katowice: Wydawnictwo Uniwersytetu Śląskiego.

CAFFarra, C., Covolo dal, E. (2012). „L'educazione è cosa di cuore”. La responsabilità degli educatori oggi. Città del Vaticano: Lateran University Press.

ChaŁAs, K. (2006). Wychowanie ku wartościom. Elementy teorii i praktyki. T. 1. Lublin-Kielce: Jedność.

ChAŁAS, K. (2007). Wychowanie ku wartościom wiejskim jako szansa integralnego rozwoju wychowanka. Lublin: Wydawnictwo KUL.

Chiona, A. (2001). Pedagogia della responsabilità. Educazione e contesti sociali. Brescia: Editrice la Scuola.

ChŁodna-BŁAch, I. (2016). Odpowiedzialność. W: K. ChaŁAs, A. MaJ (red.), Encyklopedia aksjologii pedagogicznej (s. 670-672). Radom: Polskie Wydawnictwo Encyklopedyczne Polwen.

Chudy, W. (2007). Społeczeństwo zakłamane. Warszawa: Oficyna Naukowa.

Cline, F. W., FAY, J. (2011). Miłość i logika. Jak nauczyć dzieci odpowiedzialności. Tłum. M. Piątek. Kraków: Wydawnictwo eSPe.

Czerepaniak-Walczak, M. (2007). Wychowanie. Pojęcia, procesy i konteksty. Gdańsk: Gdańskie Wydawnictwo Psychologiczne.

D'Arienzo, M. (2012). Il concetto giuridico di responsabilità. Rilevanza e funzione nel diritto canonico. Cosenza: Luigi Pellegrini editore.

Derdziuk, A. (2010). Odpowiedzialność. W: E. GigILEwICZ (red.), Encyklopedia katolicka (t. 14, kol. 334-335). Lublin: Towarzystwo Naukowe KUL.

Dүксік, W. (2010). Odpowiedzialność człowieka w kontekście indywidualnym i społecznym. Poznań: Wydawnictwo Naukowe Polskiego Towarzystwa Pedagogicznego. Oddział w Poznaniu.

FILEK, J. (1993). Etyka odpowiedzialności. W: J. PAWLica (red.), Etyka. Zarys (s. 205-225). Kraków: Uniwersytet Jagielloński. 
FILEK, J. (1995). Pytania do odpowiedzialności. Znak, 47(10), 20-27.

FILEK, J. (1998). Ontologizacja odpowiedzialności. Analityczne i historyczne wprowadzenie w problematykę. Kraków: Wydawnictwo Homini.

FILeK, J. (red.) (2004). Filozofia odpowiedzialności XX wieku. Teksty źródtowe. Kraków: Wydawnictwo Uniwersytetu Jagiellońskiego.

GaŁKowski, S. (2003). Rozwój i odpowiedzialność. Antropologiczne podstawy wychowania moralnego. Lublin: Wydawnictwo KUL.

GierulankA, D. (1972). Filozofia Romana Ingardena. Próba wniknięcia w strukturę całości dzieła. W: Z. Augustynek I IN. (red.), Fenomenologia Romana Ingardena (s. 71-90). Warszawa: Instytut Filozofii i Socjologii Polskiej Akademii Nauk.

GóRNIEWICZ, J. (1997, 2001). Kategorie pedagogiczne: odpowiedzialność, podmiotowość, samorealizacja, tolerancja, twórczość, wyobraźnia. Olsztyn: Wydawnictwo Uniwersytetu Warmińsko-Mazurskiego.

GóRniewicz, J., MichalaK, M. (1998). O niektórych paradoksach odpowiedzialności. W: A. M. DE TCHORZEWSKI (red.), Odpowiedzialność jako wartość i problem edukacyjny (s. 19-44). Bydgoszcz: Wydawnictwo „Wers”.

INGARDEN, R. (1972, 2017). Książeczka o człowieku. Kraków: Wydawnictwo Literackie.

INGARDEN, R. (1972). O odpowiedzialności i jej podstawach ontycznych. W: R. INGARDEN, Książeczka o człowieku (s. 71-169). Kraków: Wydawnictwo Literackie.

INGARDEN, R. (1994). Studia z etyki. Warszawa: PWN.

JADACKI, J. J. (2003). Odpowiedzialność i istnienie świata. W: J. J. JADACKI (red.), Aksjologia i semiotyka. Analizy i polemiki (s. 108-123). Warszawa: Semper.

Jagiello, A. (1990). Działanie ludzkie. W: J. MAKSELon (red.), Teologia dla psychologów (s. 147-176). Kraków: Wydawnictwo Naukowe Papieskiej Akademii Teologicznej w Krakowie.

JELIŃSKI, E. (2009). Odpowiedzialność (za) słowo u progu XXI wieku. W: B. SoBCZAK, H. H. ZGóŁKowa (red.), Retoryka i etyka (s. 78-83). Poznań: Wydawnictwo Poznańskie.

Jonas, H. (1996). Zasada odpowiedzialności. Etyka dla cywilizacji technologicznej. Kraków: Platon.

KANDiA-Bednarz, E. (2007). Odpowiedzialność prawna nauczyciela. Znak, 59(6), 54-63.

KAzUBowsKa, U. B. (2010). Odpowiedzialność - różnorodność ujęć i jej znaczenie w rodzinnych procesach wychowawczo-socjalizujących. W: U. B. KAZUBOwSKA (red.), Odpowiedzialność rodzicielska jako wartość. Teoria i praktyka (s. 88-121). Toruń: Wydawnictwo Edukacyjne Akapit.

KoJ, L. (1998). Powinności w nauce. T. 1: Określenie i poznawalność powinności. Lublin: Wydawnictwo UMCS.

Kościelska, M. (2007). Sens odpowiedzialności. Perspektywa psychologa klinicznego. Kraków: Oficyna Wydawnicza „Impuls”.

Kościelska, M. (2011). Odpowiedzialni rodzice. Z doświadczeń psychologa. Kraków: Oficyna Wydawnicza „Impuls”.

KowalczyK, S. (1985). Dobro. W: R. ŁuKASZYK, L. BiEŃKowski, F. Gryglewicz (red.), Encyklopedia katolicka (t. 3, kol. 1373-1375). Lublin: Towarzystwo Naukowe KUL.

KRZYwosZ-RYNKIEWICZ, K. (2007). Odpowiedzialność podmiotowa dzieci. Jak rozumieć i inspirować jej rozwój. Kraków: Oficyna Wydawnicza „Impuls”.

LEO DE, G. (1996). Psycologia della responsabilità. Roma-Bari: Laterza. 
MARI, M. (1999). Democrazia e responsabilità Maritain, Mounier, Bonhoeffer, Capitini e Verri. Roma: Armando Editore.

MiAnO, F. (2009). Responsabilità. Napoli: Guida Editori.

NowAK, M. (2008). Teorie i koncepcje wychowania. Warszawa: Wydawnictwa Akademickie i Profesjonalne.

Nowicka-KozioŁ, M. (1993). Odpowiedzialność w świetle alternatyw wspótczesnego humanizmu. Warszawa: Wydawnictwo WSPS.

Olbrycht, K. (red.) (1995). Edukacja aksjologiczna. T. 2: Odpowiedzialność pedagoga. Katowice: Wydawnictwo Uniwersytetu Śląskiego.

ORSI, M. (2002). Educazione alla responsabilità nella globalizzazione. Società della conoscenza e sfide per la scuola. Bologna: Editore EMI.

OssowsKa, M. (1957). Odpowiedzialność. W: J. HuRwIC (red.), Encyklopedia wspótczesna (s. 33). Warszawa: PWN.

PIcht, G. (1981). Pojęcie odpowiedzialności. W: G. PIcht, Odwaga utopii. Wybór K. Maurin, thum. K. Michalski (s. 231-262). Warszawa: PIW.

PlašienKovÁ, Z. (1998). Od povinnosti k zodpovednosti. W: A. REMIŠovÁ, M. SZAPuOVÁ (red.), Filozofia výchovy a problémy vyučovania filozofie (s. 154-162). Bratislava: Vydavatel'stvo Iris.

RAPA, N. ( 2013). Twórczość jako metoda wychowania do odpowiedzialności społecznej. W: A. ZAdROGA, K. SAWICKI (red.), Człowiek - społeczeństwo - gospodarka. Perspektywa odpowiedzialności społecznej (s. 143-156). Lublin: Wydawnictwo KUL.

REMBierZ, M. (2008). Refleksja moralna nad odpowiedzialnością i etosem filozofa w XX wieku. W: Z. PlašIEnKovÁ, M. RemBierz (red.), Człowiek w spoleczeństwie - Človek v spoločnosti. T. 1: Spoleczeństwo, kultura, moralność - Spoločnost', kultúra, morálka (s. 267-280). Bielsko-Biała: Wydawnictwo Akademii Techniczno-Humanistycznej.

RomanowsKa-ŁaKomy, H. (2001). Droga do człowieczeństwa. Kraków: Wydawnictwo A.

RUTKOWIAK, J. (1990). Kryzys pedagogiki a kryzys wychowania postrzegany przez pryzmat nauczycielskiej odpowiedzialności wychowawczej. W: Z. KWIECIŃSKI, L. WITKOWSKI (red.), Ku pedagogii pogranicza (s. 176-191). Toruń: Wydawnictwo UMK.

RYNIO, A. (2004). Integralne wychowanie w myśli Jana Pawła II. Lublin: Wydawnictwo KUL.

RyNIO, A. (2011). ABC wychowania do odpowiedzialności. W: P. KAWALEC, A. BŁACHUT (red.), Odpowiedzialność społeczna w innowacyjnej gospodarce (s. 210-258). Lublin: Wydawnictwo KUL.

Rynio, A. (2019). Wychowanie do odpowiedzialności. Studium teorii i praktyki pedagogiki integralnej. Lublin: Wydawnictwo KUL.

SChWARTLÄNDER, J. (1995). Odpowiedzialność jako podstawowe pojęcie filozoficzne. Tłum. J. Filek. Znak, 47(10), 5-19.

SKRECZKO, A. (2007). Wychowanie do odpowiedzialności. https://opoka.org.pl/biblioteka/I/ID/ w_do_odp.html [dostęp: 3.07.2018].

Skrzydlewski, P. (2016). Dobro. W: K. ChaŁas, A. Maj (red.), Encyklopedia aksjologii pedagogicznej (s. 256-260). Radom: Polskie Wydawnictwo Encyklopedyczne Polwen.

SoŚnICKI, K. (1973). Teoria środków wychowania. Warszawa: Nasza Księgarnia.

Suchodolski, B. (1983). Wychowanie i strategia życia. Warszawa: WSiP.

ŚLIPKO, T. (1993). Odpowiedzialność w świetle etyki chrześcijańskiej. W: J. PAWLICA (red.), O odpowiedzialności. Moralny wymiar odpowiedzialności w życiu publicznym. Materiaty III Jagiellońskiego Sympozjum Etycznego (s. 10-14). Kraków: Wydawnictwo UJ. 
TCHORZEWSKI DE, A. M. (red.) (1998). Odpowiedzialność jako wartość i problem edukacyjny. Bydgoszcz: Wydawnictwo „Wers”.

TisChner, J. (1998). Spór o istnienie czlowieka. Kraków: Wydawnictwo Znak.

TOMASCHEVSKY, K. (1988). Badania nad procesem wychowania uczniów ku odpowiedzialności w toku nauczania. Kwartalnik Pedagogiczny, 33(3).

WojtYŁA, K. (1960, 1986). Miłość i odpowiedzialność. Lublin: Towarzystwo Naukowe KUL.

WoleŃSKi, J. (1995). Analiza i odpowiedzialność. Znak, 47(10), s. 56-60.

WoLsza, K. (2005). Logiczna analiza struktury odpowiedzialności. Wokół koncepcji Józefa M. Bocheńskiego OP. W: P. MorcinIEC (red.), Haurietis de fontibus Haurietis de fontibus: spoleczno-etyczne kwestie wczoraj i dziś (s. 183-205). Opole: Redakcja Wydawnictw Wydziału Teologicznego Uniwersytetu Opolskiego.

Zavalloni, R. (1986). Educarsi alla responsabilità. Milano: San Paolo Edizioni.

\section{ODPOWIEDZIALNOŚĆ \\ TRAJEKTORIĄ W ŚWIAT DOBRA}

\section{STRESZCZENIE}

Publikacja koncentruje uwagę wokół próby odpowiedzi na trzy zasadnicze pytania: 1) Czym jest odpowiedzialność i kiedy staje się trajektorią - prowadzącą w świat dobra? 2) Jakie warunki są niezbędne, aby taka odpowiedzialność zaistniała? 3) Jak jest rozumiane samo dobro i co kryje się w pojęciu szeroko rozumianego „świata dobra”? Odpowiadając na podstawie analizy reprezentatywnej literatury przedmiotowej, autorka przybliża samo pojęcie odpowiedzialności, jak i dobra oraz opisuje warunki niezbędne do ich zaistnienia. Wśród warunków niezbędnych do zaistnienia odpowiedzialności szczególne miejsce przypisuje integralnemu wychowaniu osoby.

Słowa kluczowe: odpowiedzialność; dobro; wychowanie integralne.

\section{RESPONSIBILITY \\ AS A TRAJECTORY TO A WORLD OF GOOD}

\section{SUMMARY}

This publication focuses attention around an attempt to answer three fundamental questions: 1) What is responsibility and when does it become a trajectory - leading into the world of good? 2) What conditions are necessary for such responsibility to exist? 3) How is goodness itself understood and what is implicit in the concept of the "world of goodness" in the broadest sense? In answering this question, based on an analysis of representative literature on the subject, the author introduces the very notion of responsibility and good, and describes the conditions necessary for their occurrence. Among the conditions necessary for the existence of responsibility, she assigns a special place to the integral upbringing of the person.

Keywords: responsibility; goodness; integral education. 